\title{
Prisoner Resettlement in Scotland
}

\author{
Gill McIvor ${ }^{1}$, Hannah Graham ${ }^{2}$, and Fergus McNeill ${ }^{3}$
}

\section{Pre-print version of a book chapter in an edited book:}

McIvor, G., Graham, H., \& McNeill, F. (in press, 2018) 'Prisoner Resettlement in Scotland' in Pruin, I., Dünkel, F., \& Storgaard, A. (eds.) Prisoner Resettlement in Europe, London: Routledge.

\section{Introduction}

Prisoners and prisons have become an increasing focal point in Scottish politics and policymaking in the $21^{\text {st }}$ century. From 2000-2010, the Scottish prison population rose steadily and, despite recent reform efforts and some decreases in numbers, Scotland continues to have one of the highest prison population rates in Western Europe, at 143 per 100,000 of national population in October 2015 (Walmsley, 2016). The numbers of people leaving prison each year are considerable, as short custodial sentences are common. This chapter offers a bounded overview of the current legal and institutional infrastructure and throughcare provisions that shape the resettlement process. The chapter concludes with brief reflections on some of the challenges and unresolved issues, as well as strengths and opportunities that exist in relation to improving prisoner resettlement in Scotland. This chapter has been written during a time that we characterise as 'a season of change' in Scottish criminal justice, particularly in the midst of major restructuring of Community Justice as well as a sharp change in direction for the future of the women's custodial estate. Overtures about penal policy and a rapid rate of legislative amendments have affected the custodial estate and community punishment (Barry, 2016; Graham and McIvor, 2017). More broadly, an atmosphere of political uncertainty has stemmed from Scots going to the ballot boxes to vote four times in a two-year period: between 2014-2016 there were two consecutive Parliamentary election years (for the Scottish Parliament and the UK Parliament) and, significantly, two referenda (the 2014 Scottish independence referendum and the 2016 UK referendum on EU membership, or 'Brexit'). The impetus for diversion and decarceration has featured more prominently in Scottish political and professional discourses than that of prisoner resettlement, although the latter has gained some significant currency in recent years.

Despite some modest decreases in the Scottish prison population, the numbers of people in custody and the numbers of liberations each year remain considerable for a nation with a population of 5.4 million people. In 2015-2016, the average daily prison population encompassed 1,494 people on

\footnotetext{
${ }_{1}$ Professor of Criminology, Scottish Centre for Crime and Justice Research (SCCJR), Faculty of Social Sciences, Colin Bell building, University of Stirling, Stirling, UK, FK9 4LA.

${ }^{2}$ Lecturer in Criminology, Scottish Centre for Crime and Justice Research (SCCJR), Faculty of Social Sciences, Colin Bell building, University of Stirling, Stirling, UK, FK9 4LA.

${ }^{3}$ Professor of Criminology and Social Work, Scottish Centre for Crime and Justice Research (SCCJR), Ivy Lodge, University of Glasgow, 63 Gibson Street, Glasgow, UK, G12 8LR.
} 
remand; 3,353 short-term prisoners (serving sentences of under 4 years); and 2,828 long-term prisoners (serving sentences of 4 years and over, including life sentences and lifer recalls) (Scottish Prison Service, 2016a: 72), producing a total of 7,675. In 2015-2016, the average length of custodial sentence in Scotland was 9 1/2 months (292 days) (Scottish Government, 2017). Scotland's comparatively high use of incarceration, especially of women, has been critically linked to accusations of an increasing punitiveness in sentencing, and risk-aversion in breach decision-making for prisoners and parolees (see Tombs and Jagger, 2006; McIvor and Burman, 2011; Weaver et al., 2012).

Since the turn of the century, some landmark working groups, commissions and reports have sought to address the issues involved in reducing the prison population and to improve support for throughcare and resettlement pre-release and post-release (see McLean Committee, 2000; Scottish Executive, 2002; Scottish Prisons Commission, 2008; Commission on Women Offenders, 2012; Scottish Government, 2015a, 2016a). Furthermore, proposals for reform have been consistently advocated by Her Majesty's Inspectorate of Prisons Scotland (HMIPS).

\subsection{Language}

In Scotland, different terms are employed to describe the processes involved in transitioning through and out of prison, including throughcare, reintegration and resettlement. Although commonly used, the 're' in reintegration has been problematised in acknowledgment that not all of those that criminal justice may seek to reintegrate have ever been meaningfully integrated in the first place, highlighting the need to unsettle an implicit assumption among policymakers and professionals that what is done in the process of punishment, rehabilitation and resettlement can or should be expected to produce positive change (Carlen, 2012; Graham and McNeill, 2017). The term 'throughcare' is also in commonly use, defined as 'the provision of a range of social work and associated services to prisoners and their families from the point of sentence or remand, during the period of imprisonment and following release into the community' (Scottish Executive, 2002: 1). In Scotland, throughcare activities typically involve criminal justice social workers (whose functions are similar to those of probation and parole officers in other places) and prison staff, as well as a wide range of third (or 'voluntary') sector organisations and associations.

There are time-limits and legal meanings informing how prisoners are described and differentiated in Scotland. The broad legislative framework for the early release of prisoners has been in place since the implementation of the Prisoner and Criminal Proceeding (Scotland) Act 1993, which made a distinction between 'long-term' prisoners, those given prison sentences of 4 years or more, and 'short-term' prisoners, those given prison sentences of up to 4 years. While people are in prison, the use of the term 'prisoner' is relatively well accepted. However, in speaking about those who are released to live in the community, there are preferences among policymakers and some professionals to avoid using the terms 'offender' and 'ex-prisoner' and, instead, 'people with convictions', 'service users' or 'returning citizens' are increasingly common parlance. 
The introduction and use of the of Risk-Need-Responsivity (RNR) model in Scotland, including an adapted Scottish version of the LS/CMI criminogenic risk assessment instrument, has contributed to a moderate level of shared terminology across custodial and community-based services, albeit that the associated language and logic is necessarily centred on criminogenic risk of reoffending. This emphasis, however, has not precluded concurrent prominent uses of the language of rehabilitation and supporting desistance and reintegration among Scottish policymakers and practitioners.

\section{Preparation for Release from Prison: Key Actors and Processes}

In this section, we summarise some of the key actors and processes involved in preparing for and authorising release from prison. The subsequent section surveys the types of temporary release, early release and post-release mechanisms and service provision available in Scotland.

\subsection{The Scottish Prison Service}

Prisons in Scotland are operated by the Scottish Prison Service (SPS) and, for the sake of space, only a brief description of the SPS and its supports for prisoner resettlement are included here. Most prisons are geographically located around the central belt area of Scotland. In early 2017, there are 13 prisons which are publicly managed and two prisons that are run by private sector corporations under contract to the Scottish Prison Service. However, the number of prison facilities is set to expand in the near future with the prospect of numerous new, small 'custody in the community' prison facilities for women (for a critique and overview, see Malloch, 2015; Burman et al., 2016).

Importantly for discussions in this chapter, HMP Castle Huntly is Scotland's only 'open prison', with a capacity to accommodate 285 low supervision rated adult male prisoners (usually long-term prisoners nearing their liberation dates). Excluding the Castle Huntly open estate, all prisons in Scotland are effectively maximum security sites, with high perimeter fences, intensive levels of surveillance and an abundance of concrete and bars dominating their carceral architectures. However, within some of these prison sites, prisoners with a medium or low supervision rating can be afforded graduated regimes and increasing access to privileges. The options of release mechanisms and post-release provisions discussed in this chapter need to be understood in light of the fact that, for a significant majority of Scottish prisoners, the process of resettlement currently involves leaving a total institution.

In 2015, the Scottish Prison Service initiated the appointment of 41 'Throughcare Support Officers' who, as their title suggests, are prison officers with a dedicated role focused on supporting throughcare and resettlement. Focusing on short-term prisoners, Throughcare Support Officers communicate and collaborate with a range of actors, within the prison, as well as other statutory actors, third sector organisations, and the individual and their family, based on the use of a case management approach. For adult prisoners, contact with and support from a Throughcare Support Officer is a voluntary choice. In addition to these dedicated roles, it is common for staff across the Scottish Prison Service to collaborate with third sector organisations who offer projects and services pre- and post-release. 


\subsection{Criminal Justice Social Work}

The majority of those who serve a prison sentence in Scotland will not be subject to supervision on their return to the community. This is because most prison sentences are short-term, and there is no legal provision for (most) short-term prisoners to be subject to compulsory post-release supervision and support. Community-based supervision of long-term prisoners is undertaken by criminal justice social workers employed in local authorities (council municipalities), of which there are currently 32 in Scotland. Localism is a defining feature of Scottish community justice (see McAra, 2008).

Short-term prisoners will, in most cases, be released from prison after serving one half of their sentence without a formal requirement of supervision. Under Section 27(c) of the Social Work (Scotland) Act 1968, short-term prisoners (and their families) are entitled to request throughcare assistance on a voluntary basis from the criminal justice social work service in their local authority while in prison and in the 12-month period following release, though rates of uptake of this option remain modest. In 2014-2015, for instance, 2,700 voluntary throughcare cases commenced (Scottish Government, 2016b). Although there are no published figures on the numbers of short term prisoners released in any year, in 2013-2014 there were 12,057 sentences of less than 4 years imposed in Scotland (Scottish Government, 2015b), suggesting that voluntary throughcare may be accessed by between a fifth and a quarter of released short-term prisoners.

For long-term prisoners, throughcare begins at the point of sentence with the identification of a community-based criminal justice social worker who contributes to the sentence planning process by sharing information that may inform assessments of risk and identifying issues that might impact upon the successful resettlement of the prisoner. Prisoners subject to statutory supervision on release are included in the Integrated Case Management system which facilitates joint case management between the Scottish Prison Service (SPS) and criminal justice social work services (Malloch, 2013). On 31 March 2015, the statutory custody-based and community-based throughcare caseload for criminal justice social workers in Scotland was a total of 5,900 individuals (Scottish Government, 2016b: 20).

When a prisoner is due to be considered for release for home leave, home detention curfew with electronic monitoring, or parole or life licence, a social work report is completed and provided to assist the decision-making process. Reports for release on home leave or home detention curfew (both of which will be explained in turn shortly) are prepared for the Scottish Prison Service. For release on parole or life licence, reports are prepared for the Parole Board.

\subsection{The Parole Board for Scotland}

The Parole Board for Scotland, a non-governmental public body, has a number of statutory functions, which are set out under the Prisoners and Criminal Proceedings (Scotland) Act 1993 and the Management of Offenders etc. (Scotland) Act 2005. Cases are referred by Scottish Ministers, and the Parole Board holds responsibility for making recommendations to Ministers about the timing and conditions release for long-term determinate and indeterminate (life sentence) prisoners. In 20142015, the Scottish Government advised that there were a total of 498 cases of determinate sentence prisoners (those serving 4 years or more) eligible for consideration of early release, of which 442 
cases were referred to the Parole Board for consideration. The Parole Board for Scotland (2016: 11) recommended that 152 prisoners (or 34\% of those referred during 2014-15) be released on parole.

Parole board decisions - which are essentially risk focused, despite there being few consistent predictors of risk upon which to base their decisions (Hutton and Levy, 2002) - are informed by a range of types of information. This information comprises the 'dossier', including a home background report (prepared by a criminal justice social worker), a prison social work report, a trial judge report (where available), any relevant psychological or psychiatric reports, a sentence management report and prison misconduct reports (Parole Board for Scotland, 2017a). Home background reports are required to assess the prisoner's home background and social circumstances, update any risk assessments as appropriate, and provide the Parole Board with information about the level of supervision and support an individual may require upon release which might assist the resettlement process. In some criminal cases, victims have a right to receive information about the release of an offender. They 'may also have a right to be told when an offender is being considered for release and to make written representations (written comments)' in advance for the Parole Board to consider regarding release (Parole Board for Scotland, 2017b).

\subsection{The Third Sector and Social Enterprises}

In addition to advocating reforms and expansion of post-release statutory supervision, the Scottish Prisons Commission (2008) paved the way for increased involvement of the third sector in prisoner resettlement. The need to supervise and support short-term prisoners was specifically highlighted but the Commission noted that such support and 'supervision need not always be undertaken by qualified social workers where low levels of risk of harm permit others to take the lead' (Scottish Prisons Commission, 2008: 51). Services offered by the third sector to people leaving prison are too numerous and multi-faceted in scope to describe in any depth here; however, some specific examples are offered later in this chapter.

Complementary to but distinct from traditional notions of third sector direct service provision, examples of creativity and innovation are emerging from Scottish arts social enterprises and 'user voice' forms of representation, whose work is not necessarily preoccupied with throughcare or interventions to reduce reoffending per se. These organisations tend to work in collaboration with the Scottish Prison Service, as well as offering activities and opportunities in the community.

For example, Vox Liminis is an arts charity that offers songwriting and other arts sessions in prison, as well as in the community, involving a diverse community of voices (people with convictions, families affected by imprisonment, prison staff, criminal justice social workers, criminologists, professional musicians and singer-songwriters, other citizens) in creative conversations about punishment and reintegration. Vox Liminis has employees and volunteers who have been incarcerated and who - in addition to organising prison and community based 'sessions' - also work with participants in weekly community-based and community-building meetings (www.voxliminis.co.uk).

Street Cones is a small Scottish theatre company formed by people when they were incarcerated which has since 2015 expanded to include other actors with convictions, offering theatre 
performances, creative workshop activities, peer mentoring support for people leaving prison, and co-producing bespoke information resources for prisoners (www.streetcones.org). Freedom Bakery (www.freedombakery.org) is a social enterprise artisan bakery which operates from HMP Low Moss near Glasgow, complemented by community-based operations, offering training and work.

Finally, Positive Prison? Positive Futures (www.positiveprison.org) is a 'user voice' advocacy and representative organisation and community of interest for people affected by and interested in imprisonment, seeking to promote - through a variety of activities and forums - increased recognition of people with convictions as citizens. Their contributions to the discourses, policymaking and practices in Scottish justice have been quite prominent in recent years. For example, evidence from people who were former prisoners led the Scottish Government to include a clause in the Prisoners (Control of Release) (Scotland) Act 2015, to enable prisoner release dates to be brought forward by one or two days to avoid Friday and weekend releases when access to support services is difficult. In summary, these are a few examples of how charities and social enterprises are pioneering inspiring work with and for people leaving prison in Scotland.

\section{Forms of Release Mechanisms and Post-Release Aftercare Provisions}

This section offers a brief overview of the types of temporary release and early release mechanisms and post-release services that are available, with an important distinction between those that are statutorily mandated and those that are voluntarily chosen. It draws attention to the particular types of orders and licences involved and, where relevant, gives examples of the categories of offences and offenders that they are designed for.

\subsection{Open Prisons and Temporary Release on Home Leave}

Open prisons and home leave form an important part of the throughcare process for long-term prisoners in terms of offering a graduated return to visiting and living in the community, maintaining family contact and assisting the Parole Board for Scotland to determine a prisoner's suitability for release as reflected in their ability to cope outside the prison environment (Armstrong et al., 2011; Malloch, 2013). Home leave is a form of temporary release. Temporary release can take the form of escorted leave, where the prisoner is escorted for the duration of the visit, or unescorted leave, in which the prisoner makes their own way to the leave address and back. Home leave of up to seven nights per month can be granted to prisoners who have attained a low security category, who have served an appropriate amount of time in custody (dependent on the length of sentence) and who are being held in an open prison or a 'top end' facility (closed prisons which allow some prisoners to be entitled to be considered for special escorted leave) (Scottish Executive, 2007). In the financial year 2015-2016, an estimated 16,899 days of temporary release on home leave were granted to Scottish prisoners, predominantly to those within the open prison estate (15,762 days) (Scottish Prison Service, 2016b). Given that the Open Estate contains only around 3 per cent of the total Scottish prison population (Scottish Prison Service, 2017a), it is clear that very few prisoners overall receive home leaves prior to their release. During the same year, there were 27 recorded cases of prisoners 
re-offending while on home leave and/or breaking the rules of home leave (Scottish Prison Service, 2016b).

\section{2 'Automatic' Early Release and the Prisoners (Control of Release) (Scotland) Act 2015}

The release arrangements discussed above - especially those for long-term prisoners - have become increasingly controversial in recent years. As noted above, under the Prisoners and Criminal Proceedings (Scotland) act 1993, long-term prisoners had been eligible for consideration for parole at the halfway point in their sentences. If they did not secure release on parole licence, they were released automatically at the two-thirds point of their sentence on a 'non-parole licence'. The standard conditions of the two forms of licence, and the types of additional conditions that could be added by the Parole Board, were the same in both cases.

This arrangement became the subject of heated debate between 2003 and 2007, partly due to exceptional but high-profile crimes by prisoners who had absconded from the open prison estate, by people completing their sentences in the community after early release. Indeed, the then First Minister, Jack McConnell, faced repeated questions in Parliament, eventually committing to end automatic release. Legislation (the Custodial Sentences and Weapons Act 2007) was duly passed just before Parliamentary elections in 2007, but McConnell's Labour administration was defeated at the polls and the incoming Scottish National Party's minority government never implemented the 2007 Act, which was deemed ill-conceived and unaffordable by the independent Scottish Prisons Commission (2008).

However, the current (SNP) Cabinet Secretary for Justice, Michael Matheson, did bring forward an alternative Prisoners (Control of Release) Bill in 2015. The initial Bill made provision to end automatic release at the two-thirds point. As experts pointed out, this created the prospect not just of significantly increasing the prison population but also of allowing prisoners to 'max out' and be released without any support or supervision. The Prisoners (Control of Release) (Scotland) Act 2015 was eventually passed with an amendment such that no long-term prisoner could be released later than 6 months before the expiry of their full sentence. This was intended to ensure that the critical first few months after release would be both supervised and supported. As one of the most critical expert commentators on the Act has noted:

'Only time will tell what impact these reforms will have on the process of reintegration, but the consensus among expert witnesses, despite the government's claims to the contrary, is that they will hinder rather than help that process' (Barry, 2016: 99).

\subsection{Electronic monitoring}

Electronic monitoring can be used with adults and young people subject to various forms of statutory supervision in Scotland. In the case of prisoners, the most common use is as an early release mechanism using a radio frequency tag and Home Detention Curfew (HDC). HDCs were introduced in 2006 through the Management of Offenders etc. (Scotland) Act 2005 for prisoners serving sentences of less than four years and enable prisoners to be liberated up to six months prior to their release date subject to an electronically monitored curfew of between nine and 12 hours per day. In 
the first week of January 2017, 281 prisoners were being electronically monitored on a HDC licence, out of a prison population total of 7,549 prisoners (Scottish Prison Service, 2017b). Electronic monitoring can also be imposed as a condition of parole for periods of up to 24 hours per day, though its use in this context is very limited and when EM is imposed in the context of parole, curfews of more than 12 hours are not routinely imposed (McIvor and Graham, 2016).

An expert working group on electronic monitoring have recently recommended that greater consideration is given as to how EM might be used within the custodial estate for reintegrationoriented activities and temporary leave and its use as a form of early release to support the process of reintegration increased (Scottish Government, 2016a).

\subsection{Violent Offenders and Sex Offenders}

Legislative provisions in the form of statutory throughcare have been developed to manage the release of those convicted of particular categories of offence who are deemed to present a particular risk of serious harm to the public. The types of orders and throughcare mechanisms differentiate between violent offenders and sex offenders. Supervised Release Orders (SROs) were introduced in Scotland under Section 209 of the Criminal Procedure (Scotland) Act 1995. The legislation enables the court, where sentencing an offender (with the exclusion of sex offenders) to a sentence of between one and four years in prison to impose a period of compulsory supervision for a period of up to one year - but not extending beyond the expiry date of the original sentence - following release where the court considers that the individual poses a risk of harm to the public. SROs do not require the consent of the offender. The purpose of the order, and any conditions attached to it, is 'securing the good conduct of the person, or preventing, or lessening the possibility of, his committing a further offence' (Scottish Executive, 2004: para 370.2.3).

People convicted of sexual offences can be subject to different measures, depending on the length of custodial sentence imposed. One of the few groups of short-term prisoners who are subject to compulsory supervision following release are those convicted of sexual offences and in respect of whom a prison sentence of between 6 months and up to 4 years has been imposed. These prisoners can be released unconditionally at the half-way point of their sentence but are subject to a shortterm licence involving supervision in the community until the end date of their original prison sentence. Any conditions attached to the short-term licence are determined by Scottish Ministers through the Parole Unit of the Scottish Government, rather than the Parole Board for Scotland.

Scottish courts are able to impose an extended sentence involving an additional period of statutory supervision on an offender, who receives a custodial sentence of any length for a sexual offence or offence with a significant sexual element, or a sentence of 4 years or more imprisonment for a violent offence. Extended sentences may only be imposed in indictment cases (i.e. under 'solemn' as opposed to 'summary' criminal procedure) where it is considered by the court that the period of supervision that would normally be associated with the custodial sentence imposed would not be adequate for the protection of the public from serious harm. The resulting sentence consists of the custodial term along with a further period (the extension period) of up to ten years during which the individual is released on licence. 
Concerns about the potential risks posed by serious violent and sexual offenders also underpinned the introduction in Scotland of an Order of Lifelong Restriction (OLR), following the publication of the MacLean Committee (2000) report. Introduced in mid-2006, an Order of Lifelong Restriction can be made by the High Court in Scotland in respect of an offender (of any age) who is convicted of a serious violent or sexual offence, or of an offence which that suggests a tendency for serious violent, sexual or life-endangering offending. Under an OLR - which can only be imposed following a risk assessment undertaken by an accredited risk assessor - the offender is managed through a series of stages from maximum security through to supervised release into living in the community. The OLR allows for a greater degree of intensive supervision to manage the prisoner's criminogenic risk and, as the name implies, the period of supervision in the community lasts for the whole of the person's life. Individuals subject to OLRs who are deemed not to be fully complying with supervision and monitoring may be returned to more restrictive forms of supervision, including being returned to custody. There are no published figures on the number of persons subject to an OLR in Scotland. However, between April 2015 and March 201652 prisoners on OLRs were referred to the Parole Board for Scotland, none of whom were granted release (Parole Board for Scotland, 2017c).

Complementary and often concurrent to statutory risk management arrangements supervising the reintegration of sex offenders, there is the voluntary option of taking part in Circles of Support and Accountability (CoSA). In Scotland, these are led by third sector services and community volunteers. There is limited available information on the rate of uptake of Circles across Scotland, but it is thought to be quite low. Armstrong and Wills (2014) reviewed Circles of Support and Accountability available in the area of Fife, finding that it was well supported and positively perceived by participants, volunteers and agencies external to the CoSA process.

\subsection{Life Licences}

Prisoners serving a life sentence - who are serving indeterminate sentences - can have their case considered by the Parole Board for Scotland once the punishment part of their sentence (that is, the minimum period of time that the sentencing judge had indicated they must spend in custody) has expired. All life sentence prisoners have a minimum sentence set which is at the discretion of the judiciary, although whether and when a person is released is determined by the Parole Board. Once released, life sentence prisoners are subject to a statutory licence for the remainder of their lives. The supervision requirement of the licence may be lifted, but this can only be considered after ten years.

\subsection{Mentoring}

In recent years, the Scottish Government has provided funding for several initiatives to support throughcare and resettlement through the Reducing Reoffending Change Fund programme. A central feature of recent resettlement initiatives has been the involvement of third sector and public agencies in collaboration in Public Social Partnerships (PSPs) to deliver coordinated mentoring services, some of which target prisoners serving short sentences (Clark et al., 2013; Mulholland et al., 2016). Guidance provided by the Scottish Government (2012: 2) defines mentoring as: 
' $\ldots$ a form of intervention in which an individual (who may be a peer, a professional or a volunteer) builds a one-to-one relationship with the offender with the aim of supporting them to achieve positive outcomes in their lives. Some mentoring schemes have a specific focus, for example, helping offenders prepare for employment. Others may offer offenders more general support, such as helping them to access mainstream services or to comply with court orders. Mentoring may be delivered in prison, through the gate or in the community.'

Initiated in 2013, these schemes aim to provide mentoring support for particular groups; some, for instance, are aimed at women, others at people with histories of persistent offending. For example, the Routes out of Prison initiative involves a partnership between multiple public and third sector organisations to offer life coaching and peer mentoring, as well as family support, pre- and postrelease (see Scottish Government, 2011; Schinkel and Whyte, 2012).

An independent evaluation of the Shine mentoring project for women found that $60 \%$ of women who engaged with mentoring in prison continued to engage with it in the community for 2 months or more following release (Ipsos MORI, 2015). Mentees who were interviewed reported that mentoring had a significant impact on their lives. However, although a considerable proportion of mentees had made progress in achieving short and medium-term outcomes, a significant number of women either failed to engage with or dropped out of the initiative, thereby affecting the evaluation results (Ipsos MORI, 2015).

\section{Non-Compliance, Breach and Recall of Released Prisoners}

There are particular decision-making processes in place for members of authorising agencies such as the Scottish Prison Service and the Parole Board for Scotland to make decisions about what type and level of non-compliance constitutes a breach and whether that should result in recall to prison. The Parole Board for Scotland is responsible for considering responses to non-compliance and for the decision to recall to prison individuals who are released on parole licences or non-parole licences (other statutory forms of post-release supervision for long-term prisoners), as well as for short-term prisoners convicted of sexual offences and all prisoners subject to an extended sentence who are deemed to have broken the conditions of their licence. Recalled prisoners have no opportunity to make representation prison to being returned to custody where they are informed of the reasons for the revocation of their licence and of their right to make representations to the Scottish Ministers. In the event that a prisoner makes such written representations, the case will be referred to the Parole Board who determine whether or not the revocation of the licence should be cancelled.

There has been an increase in prison recall rates in Scotland in recent years. During 2014-15, 53 licensees were reported to the Parole Board (2016: 14) for behaviour potentially constituting grounds for recall: warning letters were issued to 10 licensees; 41 were recalled to custody; one case was withdrawn and another case had no action taken. Weaver and colleagues (2012) sought to identify factors and reasons for the increases through analysing data published by the Scottish Government and Parole Board for Scotland. Finding that the proportion of cases that are recalled to custody following release - and their diversity - has increased in recent years, with a notable increase in the number of recalls of prisoners given extended sentences, they suggest that criminal justice 
social workers may increasingly be acting pre-emptively to initiate recall of individuals who pose particular concerns for public safety (Weaver et al., 2012). More recent research into compliance and breach in Scotland by Barry and colleagues (Barry et al., 2015, in Barry, 2016: 97) has found that breaches of licence conditions are more likely the result of "technical breaches" (failing to attend appointments or disclose new relationships) rather than further offending.'

In terms of early release from prison with electronic monitoring, breach and recall decisions for prisoners on a Home Detention Curfew are made by the Scottish Prison Service. In the one year period of 2016, 85\% of HDC licences were completed, with small variations by month (G4S, 2017). Recent research on the use of electronic monitoring with prisoners found that prison staff themselves identified relatively solid and stable uses of EM with prisoners (see McIvor and Graham, 2016). However, in relation to breach and recall decision-making, participants spoke of an overarching culture of risk-averse decision-making by prison staff, with a common preference to err on the side of caution for the purposes of public perceptions and public protection (McIvor and Graham, 2016). The Parole Board considers appeal-like representation from prisoners who have been recalled to prison by the SPS for breach of their HDC licence. Nellis (2016: 187) observes that the Parole Board has 'found against' (i.e. overturned) decisions to recall tagged prisoners 'in a third of cases.'

\section{Challenges and Unresolved Issues}

There are a number of challenges and unresolved issues where significant and sustained progress is yet to be made. In an analysis of throughcare provision in Scotland, Malloch (2013) identifies numerous factors which appear to limit effectiveness, including: the inability of some prisoners to access services; the provision of programmes in isolation resulting in fragmentation (and repetition and overlap) in provision; the use of different assessment tools by different agencies; the provision of services that are service-led rather than needs-led; and an emphasis on reducing the risk of reoffending - through programmes aimed at tackling offending - rather than reintegration, desistance and the practical implications thereof.

In conducting a review of criminal justice services, Audit Scotland (2012) criticised the existing provisions for the resettlement and reintegration of prisoners, noting that prisoners were often located at some distance from their homes and communities. Allocation to a certain prison facility in Scotland is not necessarily heavily influenced by that's person home address. Other factors such as gender, age and risk or security classification tend to trump locality considerations in everyday practice. Audit Scotland (2012) observed that there was insufficient information available to prisons and local authorities to improve the planning and management of throughcare services in prison and in local communities. They summarise the issues in saying:

'The spread of prisoners from all councils in each prison also makes it difficult for SPS to ensure that every prisoner gets access to appropriate services and for prison link centre staff to liaise with staff in all of the 32 councils' (Audit Scotland, 2012: 22).

This issue has been particularly pronounced in respect of imprisoned women who make up a small (but persistently growing) proportion of the Scottish prison population. Because the number of 
imprisoned women is relatively small they are more likely than men to be detained in establishments at some distance from their homes, making it more difficult to maintain relationships, including those with their children. Reducing the female prison population has been a key priority of the Scottish Government in recent years, prompting an announcement in June 2015 that the existing female prison estate - comprising a national facility in central Scotland exclusively for women with smaller numbers of women held in male establishments - would be replaced by a significantly smaller national facility for the most serious female prisoners and five community-based custodial units offering tailored support, each with of which will be able to accommodate up to 20 women. This bold vision of decarceration - which envisages a more than halving of the female prison population - will, however, only be achieved through the increased use of community based measures to reduce the number of women receiving short custodial sentences.

Audit Scotland (2012) also identified a disjuncture between the services available in the community and the perceptions of prisoners regarding their anticipated needs on release and in the process of reintegration. Thus, for example, while services tended to focus on substance misuse issues and housing, prisoners themselves tended to identify financial needs as a priority (see also McIvor and Barry, 1998).

One of the areas that straddles both this section on challenges and the next section on strengths and opportunities is the area of housing and accommodation for people leaving prison. With regards to rights in the resettlement process, Scotland has been heralded as having 'possibly the strongest legal framework in the world in relation to protecting people from homelessness' (Anderson and Serpa, 2013: 14), because all local authorities have a statutory duty to provide settled accommodation for all unintentionally homeless people, as well as a duty to provide temporary accommodation during the process of investigating a homelessness application (Dore, 2015). The legal provisions and principles are excellent. Yet, in practice, the availabilities and complexities of accessing safe and affordable accommodation upon release from prison remains an acute challenge requiring more resources and support, especially given the documented links between homelessness and reoffending (see Dore, 2015; Reid Howie Associates, 2015).

\section{Strengths and Opportunities for Advancing More Effective Approaches}

The provision of effective throughcare services to support the desistance and resettlement of prisoners in Scotland is not without its challenges, although there is evidence emerging as to what types of approaches are more effective (see McNeill and Schinkel, 2016). Malloch (2013) identified numerous positive strengths in Scotland, including: strong relationships between the Scottish Prison Service, criminal justice social work services and the third sector; opportunities for shared understanding of roles and remits that promote openness and trust between agencies; using strengths-based approaches before and post-release; ensuring continuity of throughcare service provision in transitioning from prison to the community; promoting flexible and non-judgmental relationships between service users and providers; and the capacity for innovative services to be financially sustained. These resonate with the findings of others on factors and supports for desistance and community reintegration (see Malloch et al., 2013; Graham, 2016; McNeill and Schinkel, 2016). 
Malloch (2013) also concludes, however, from her review of throughcare in Scotland that effective responses require partnership working between criminal justice actors and agencies and other actors and agencies spanning the areas of housing, employment, social security and benefits, health and social care because the social problems that commonly underlie offending are rooted in wider forms of economic and social disadvantage. Thus while the criminal justice system may have a legislated responsibility to support and/or supervise individuals on their release from prison, the issue is essentially about concurrently securing access to social justice and social goods. This requires a focus on community reintegration and an associated effort to address the immediate and longer-term practical issues that people leaving prison encounter, rather than narrowly on reducing reoffending per se.

There is, perhaps, growing recognition in Scotland that resettlement raises questions of social justice as much as criminal justice. Supporting desistance and reducing reoffending are seen as being intrinsically and inescapably linked to supporting social re/integration. But as we noted at the outset of this chapter, many of the people that are routinely processed in and out of Scottish prisons especially on short sentences - are amongst the most marginalised and dis-integrated of Scottish citizens (see Nugent and Schinkel, 2016). Addressing and resolving their exclusion depends not just on better criminal law and criminal justice practice, but also on the motivation, resources and coordination of all arms of Government and of civil society (McNeill and Schinkel, 2016).

\section{References}

Anderson, I., and Serpa, R. (2013) 'The Right to Settled Accommodation for Homeless People in Scotland: A Triumph of Rational Policymaking?' European Journal of Homelessness, 7(1): 13-39.

Armstrong, S., Malloch, M., Nellis, M., and Norris, P. (2011) Evaluating the Effectiveness of Home Detention Curfew and Open Prison in Scotland, Edinburgh: Scottish Government.

Armstrong, S., and Wills, D. (2014) A Review of the Fife Circles of Support and Accountability Project commissioned by Sacro, Final Report, Glasgow: Scottish Centre for Crime and Justice Research.

Audit Scotland (2012) Reducing Reoffending in Scotland, Edinburgh: Audit Scotland.

Barry, M. (2016) 'The Automatic Early Release and Supervision of Prisoners in Scotland' Edinburgh Law Review, 20: 94-99.

Barry, M., Weaver, B., Moodie, K., and Piacentini, L. (2015) 'Regulating Justice: The Dynamics of Compliance and Breach in Criminal Justice Social Work in Scotland', ESRC grant number $\mathrm{ES} / \mathrm{J} 02340 \mathrm{X} / 1$.

Burman, M., Malloch, M., and McIvor, G. (2016) 'A Comparison: Criminalised Women in Scotland', in Annison, J., Brayford, J., \& Deering, J. (eds.) Women and Criminal Justice: From the Corston Report to Transforming Rebabilitation, Bristol: Policy Press.

Carlen, P. (2012) Against Rehabilitation: For Reparative Justice: 22 ${ }^{\text {nd }}$ Eve Saville Memorial Lecture - available online at http://tinyurl.com/p8bcrtm (accessed 27/11/2015).

Clark, I., Simpson, L., and Shipway, R. (2013) Reducing Reoffending Change Fund Evaluation of Year 1 Public Social Partnership Development, Edinburgh: Scottish Government Social Research. 
Prisoner Resettlement in Scotland - book chapter by Gill McIvor, Hannah Graham and Fergus McNeill (2018)

Commission on Women Offenders (2012) Report of the Commission on Women Offenders, Edinburgh: Commission on Women Offenders.

Dore, E. (2015) Prison Leavers and Homelessness [IRISS Insight 29], Glasgow: Institute for Research and Innovation in Social Services (IRISS).

G4S (2017) Electronic Monitoring to the Criminal and Youth Justice Systems in Scotland: Statistical Bulletin 1 January 2016 - 31 December 2016, Glasgow: G4S Scotland.

Graham, H. (2016) Rehabilitation Work: Supporting Desistance and Recovery, London: Routledge.

Graham, H., and McIvor, G. (2017) 'Advancing Electronic Monitoring in Scotland: Understanding the Influences of Localism and Professional Ideologies’ European Journal of Probation, 9 (1): 62-79.

Graham, H., and McNeill, F. (2017) 'Desistance: Envisioning Futures' in Ayres França, L., and Carlen, P. (eds.) Alternative Criminologies, London: Routledge.

Hutton, L., and Levy, L. (2002) Parole Board Decisions and Release Outcomes, Edinburgh: Scottish Executive Central Research Unit.

Ipsos MORI (2015) Evaluation of Shine Women's Mentoring Project - Final Report, Edinburgh: Ipsos MORI.

Lewis, S. (2015) Therapeutic Correctional Relationships: Theory, Research and Practice, London: Routledge.

MacLean Committee (2000) Report of the Committee on Serious Violent and Sexual Offenders, Edinburgh: Scottish Executive.

Malloch, M. (2013) The Effects of Effective Through-Care Part 2: Scottish Review, Glasgow: Scottish Centre for Crime and Justice Research (SCCJR).

Malloch, M. (2015) 'Discursive Detours on the Route to Justice for Women' The Scottish Journal of Crime and Justice Studies, 21: 25-36.

Malloch, M., McIvor, G., Schinkel, M., and Armstrong, S. (2013) The Effects of Effective Through-Care Part 1: International Review, Glasgow: Scottish Centre for Crime and Justice Research (SCCJR).

McAra, L. (2008) 'Crime, Criminology and Criminal Justice in Scotland' European Journal of Criminology 5(4): 481-504.

McIvor, G., and Barry, M. (1998) Social Work and Criminal Justice Volume 7: Community-based Throughcare, Edinburgh: The Stationery Office.

McIvor, G., and Burman, M. (2011) Understanding the Drivers of Female Imprisonment in Scotland, Stirling and Glasgow: Scottish Centre for Crime and Justice Research.

McIvor, G., and Graham, H. (2016) Electronic Monitoring in Scotland [report] Stirling: University of Stirling and Criminal Justice Programme of the European Commission.

McNeill, F., and Schinkel, M. (2016) 'Prisons and Desistance' in Jewkes, Y., Bennett, J., and Crewe, B. (eds.) Handbook on Prisons (2 ${ }^{\text {nd }}$ ed.) London: Routledge.

Mulholland, C., Eunson, J., Murray, L., Bowen, L., McIvor, G., Malloch, M., Whyte, B., Kirkwood, S., and McNeill, F. (2016) Evaluation of the Reducing Reoffending Change Fund Final Report, Edinburgh: Scottish Government Social Research.

Nellis, M. (2016) 'The Strategic Failure of Electronic Monitoring in Scotland' in Croall, H., Mooney, G., and Munro, M. (eds.) Crime, Justice and Society in Scotland, London: Routledge.

Nugent, B., and Schinkel, M. (2016) 'The Pains of Desistance' Criminology \& Criminal Justice, 16(5): 568-584. 
Prisoner Resettlement in Scotland - book chapter by Gill McIvor, Hannah Graham and Fergus McNeill (2018)

Parole Board for Scotland (2016) Parole Board for Scotland Annual Report 2014-2015, Edinburgh: Parole Board for Scotland.

Parole Board for Scotland (2017a) 'The Role of the Board' http://www.scottishparoleboard.gov.uk/page/role of the board (Accessed 12/01/2017).

Parole Board for Scotland (2017b) 'Victims and Families' http://www.scottishparoleboard.gov.uk/page/victims and families (Accessed 12/01/2017).

Parole Board for Scotland (2017c) The Parole Board for Scotland Annual Report 2015-2016, Edinburgh: Parole Board for Scotland.

Reid Howie Associates (2015) Housing and Reoffending: Supporting People who Serve Short-term Sentences to Secure and Sustain Stable Accommodation on Liberation, Edinburgh: Scottish Government Social Research.

Schinkel, M., and Whyte, B. (2012) 'Routes out of Prison Using Life Coaches to Assist Resettlement' The Howard Journal 51(4): 359-371.

Scottish Executive (2002) Throughcare - Developing the Service: Report of the Tripartite Group, Edinburgh: Scottish Executive.

Scottish Executive (2004) Long Term Prisoners and Prisoners Subject to Supervised Release Orders: Guidance for Social Work Services, Edinburgh: Scottish Executive.

Scottish Executive (2007) Integrated Practice Guidance for Staff involved in the Home Leave Guidance Process, Edinburgh: Scottish Executive Home Leave Working Group.

Scottish Government (2011) Case Study 145: What Working in Tackling Poverty - Routes out of Prison (RooP) Project Edinburgh: Scottish Centre for Regeneration, Scottish Government.

Scottish Government (2012) Reducing Reoffending Change Fund - Guidance for Applicants http://www.gov.scot/Resource/0040/00406959.pdf (Accessed 28/01/2017)

Scottish Government (2015a) Report of the Ministerial Group on Offender Reintegration, Edinburgh: Justice Division, Scottish Government.

Scottish Government (2015b) Prison Statistics and Population Projections Scotland 2013-14, Edinburgh: Scottish Government.

Scottish Government (2016a) Electronic Monitoring in Scotland Working Group Report, Edinburgh: Justice Division, Scottish Government.

Scottish Government (2016b) Criminal Justice Social Work Statistics in Scotland 2014-2015, Edinburgh: Scottish Government.

Scottish Government (2017) Monthly Safer Communities and Justice Brief - January 2017, Edinburgh: Justice Analytical Services, Scottish Government.

Scottish Prisons Commission (2008) Scotland's Choice: Report of the Scottish Prisons Commission, Edinburgh: Scottish Prisons Commission.

Scottish Prison Service (2016a) Scottish Prison Service Annual Report and Accounts 2015-2016, Edinburgh: Scottish Prison Service.

Scottish Prison Service (2016b) 'Home Leave Freedom of Information Request HQ16197, 14 December 2016.' Available at: http://www.sps.gov.uk/FreedomofInformation/FOI4699.aspx (Accessed 10/01/2017).

Scottish Prison Service (2017a) Scottish Prison Service Annual Report and Accounts 2016-17, Edinburgh: Scottish Prison Service. 
Prisoner Resettlement in Scotland - book chapter by Gill McIvor, Hannah Graham and Fergus McNeill (2018)

Scottish Prison Service (2017b) 'Scottish Prison Service Prison Population, as at Friday $6^{\text {th }}$ January 2017’ http://www.sps.gov.uk/Corporate/Information/SPSPopulation.aspx (Accessed 10/01/2017).

Tombs, J., and Jagger, E. (2006) 'Denying of Responsibility: Sentencers' Accounts of their Decisions to Imprison’ British Journal of Criminology, 46(5): 803-821.

Walmsley, R. (2016) World Prison Population List (11 ${ }^{\text {th }}$ ed.), London: Institute for Criminal Policy Research. Available online at:

http://www.icpr.org.uk/media/41356/world prison population list 11th edition.pdf (Accessed 10/01/2017).

Weaver, B., Tata, C., Munro, M., and Barry, M. (2012) 'The Failure of Recall to Prison: Early Release, Front-Door and Back-Door Sentencing and the Revolving Prison Door in Scotland' European Journal of Probation 4(1): 85-98. 